\title{
Long-term changes in microphytobenthos in a Brittany estuary after the 'Amoco Cadiz' oil spill
}

\author{
Catherine Riaux-Gobin
}

Centre d'Etudes d'Océanologie et de Biologie marine, F-29211 Roscoff, France

\begin{abstract}
After the 'Amoco Cadiz' oil spill (Mar 1978), a 4 yr survey of the microphytobenthos (cell numbers and chlorophyll a content) was carried out on a mud flat polluted by petroleum hydrocarbons. There was an obvious peak of microphytic biomass 7 mo after the spill, a decrease during 1979-1980. and a slow increase again in 1981. Moreover an annual pattern in biomass variations, involving early spring and autumn maxima, was noticed for 1979-80-81, whereas this seasonal cycle did not appear in 1978. During the unexpected increase in chlorophyll a content in autumn and winter 1978, a bloom of Euglenophyta and small epipelic diatoms was observed. Results suggest that the hydrocarbons affected the long-term trend of the biocenosis.
\end{abstract}

\section{INTRODUCTION}

Very few papers deal with the consequences of oil pollution on microphytobenthos communities, whereas numerous studies have been carried out on physiological responses to pollution of phytoplankton in culture (Parsons et al. 1976, Prouse et al. 1976, Hsiao 1978), artificial enclosures (meso- and microcosms) (Elmgren \& Frithson 1982, Oviatt et al. 1982, Skjoldal et al. 1982), and in natural populations (Gordon \& Prouse 1973, Vargo et al. 1982). Phytoplankton responses to simulated or accidental pollution are diverse and depend upon the species, pollution level, nature of oil pollutant and environmental factors. The results are sometimes contradictory and it is difficult to interpret and generalize them. Microflagellates and benthic microalgae seem to be more resistant to pollution than pelagic diatoms (cf. Hsiao 1978, Lacaze 1978, Dahl et al. 1983). The mucus sheath covering epipelic diatoms and their migratory capacity can preserve them from serious damage. Nevertheless, these algae can also be affected by oil pollution and the level of their response depends in part upon the physical properties of the pollutant. Contact with a water/oil emulsion seems to be very harmful (Lacaze 1978). On the other hand, stimulating effects on the growth rate of phytoplankton (Parsons et al. 1976, Prouse et al. 1976) as well on that of microphytobenthos (Lacaze 1978) have been observed, especially at low levels of pollution. It has been also suggested by several authors working on in situ populations (cf. Johansson et al. 1980), or on enclosed planktonic ecosystems (Vargo et al. 1982 , Dahl et al. 1983), that pollution can reduce grazing and thereby induce a secondary microalgal bloom. Ecological surveys of oil polluted benthic microalgal communities are scarce. Bakke et al. (1982), working on a sandy sediment artificially polluted by a relatively low level of hydrocarbons $(\simeq 110 \mathrm{ppb})$, did not find significant differences in the chlorophyll a concentration of the polluted and reference sediments

The pollution caused by the 'Amoco Cadiz' shipwreck on the Brittany coast was one of the most severe to be reported (D'Ozouville et al. 1978, Law 1978). Some 220,000 t of Arabian light petroleum was carried by this supertanker, and Gundlach et al. (1983) have calculated that about $62,000 \mathrm{t}$ of oil were washed into the intertidal zone. Several surveys of microphytobenthic polluted communities were carried out after this oil spill. Some of these were initiated a few days before the arrival of hydrocarbons at the coast: at Corn ar Gazel, a sandy beach in the Aber Benoit (Bodin \& Boucher 1983), and on an intertidal mud flat in the Dourduff estuary (Boucher et al. 1982, Riaux 1982), whereas another study started some months later (Plante-Cuny et al. 1980) in a heavily polluted saltmarsh of the Ile Grande.

The present study deals with long term variations in microphytobenthos biomass (chlorophyll a) and species successions on a mud flat in the Dourduff estuary. The aim of the survey was to determine how 
far hydrocarbons had changed the benthic community, altered the seasonal cycle, and promoted or adversely affected the growth of some microphytes. In previous studies on this mud flat (Riaux 1982, 1983) it has been shown that the microalgal biomass is affected by shortterm variations which are related to the diurnal tidal cycle and the neap-spring tidal cycle. Here the variations over monthly and yearly cycles are discussed.

\section{MATERIALS AND METHODS}

The sampling station was located on a mud flat in the upper part of the Dourduff estuary at about midtide level. The Dourduff location is virtually unpolluted from local sources except for a little boat traffic. Sediment samples were collected in triplicate every month (from Mar 1978 to Aug 1981) with a $5.4 \mathrm{~cm}$ (I. D.) plexiglass corer, at low tide, during neap tide periods. The first sampling was performed before the oil arrived on shore. Only data concerning the top layer of the sediment $(0$ to $0.5 \mathrm{~cm})$ are discussed here. Chlorophyll a (Chl a) and phaeopigments (Phaeo) were extracted from the sediment according to the method of PlanteCuny (1974), but without grinding the samples. Pigment concentration, used as a biomass indicator, was determined according to the method of Yentsch \& Menzel (1963), using a Turner 111 fluorometer equipped with an $\mathrm{R} 136$ phototube and using Lorenzen's (1966) equations adapted to sediments. Petroleum aliphatic hydrocarbons were extracted in $\mathrm{CCl}_{4}$ and concentrations were measured by the infra-red spec- trophotometric method (Causse \& Mestres 1975). For this last analysis only 1 sediment core was normally collected. The petroleum data from all the layers sampled are presented here. Microphytes were harvested from the sediment using the migration technique on lens tissue (Grade 105 Whatman) described by Eaton \& Moss (1966). Only diatoms and Euglenophyta (the most abundant microphytes) were considered. Mathematical treatment of data was performed using a 'tendency extracting' program (cf. Laurec \& Le Gall 1975).

\section{RESULTS}

\section{Aliphatic hydrocarbons}

After the 'Amoco Cadiz' shipwreck the oil rapidly fouled the rocky shore and sandy beaches of North Brittany ( 1 to $8 \mathrm{~d}$ for all the $140 \mathrm{~km}$ polluted coast). Subtidal sediments and upper zones of embayments were more slowly polluted. Several studies are now available on the different forms of behaviour of hydrocarbons from the 'Amoco Cadiz' in the water column and sediments and on the different patterns of oil degradation (cf. Gundlach et al. 1983).

In the Dourduff mud flats, polluted by water/oil emulsion, the highest concentrations of aliphatic hydrocarbons were observed $3 \mathrm{mo}$ after the oil spill (Fig. 1). The oil slowly penetrated into the sediment and reached very high values (up to 9,000 ppm in Jul 1978). After this first pollution stage, which lasted $4 \mathrm{mo}$, the level of pollution decreased gradually, the

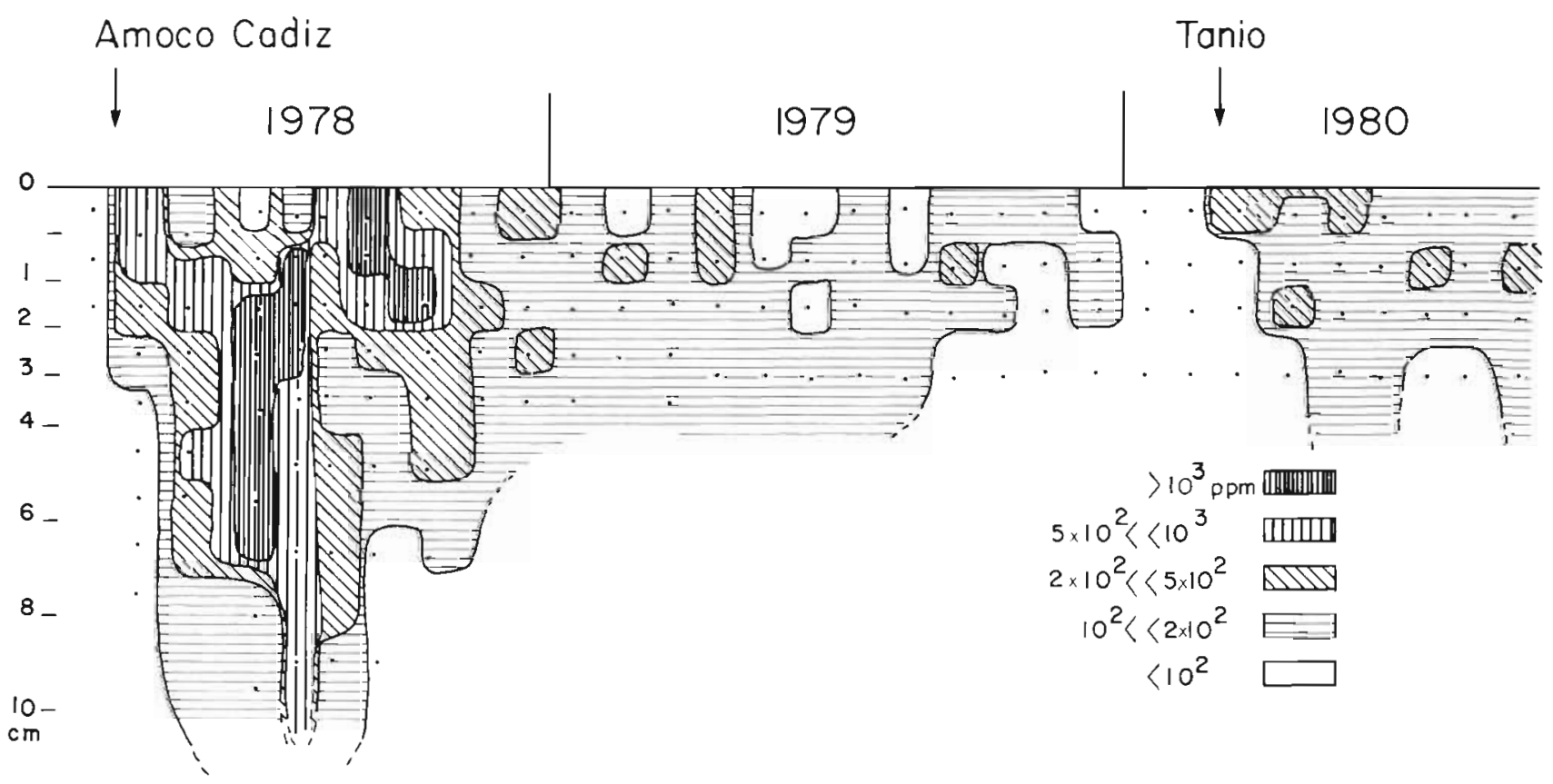

Fig. 1. Vertical distribution of aliphatic hydrocarbons in the Dourduff mud flat (1978-1980). Arrows: shipwrecks of 'Amoco Cadiz' and 'Tanio' 


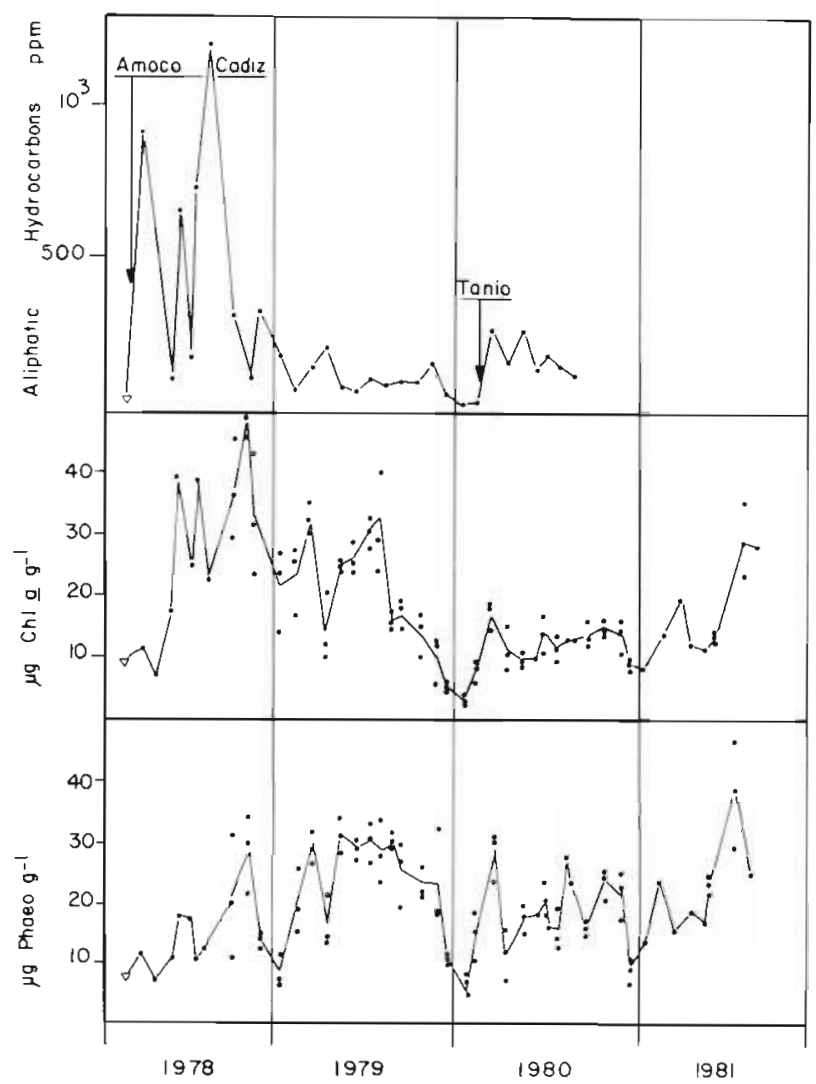

Fig. 2. Aliphatic hydrocarbons, chlorophyll $a$ and phaeopigments in the top layer of the sediment $(0$ to $0.5 \mathrm{~cm})$. Open symbols represent the prepollution data. The curve (for $\mathrm{Chl}$ a and Phaeo) represents the mean of the replicates (black symbols)

lowest layers of the mud being decontaminated first (Fig. 1). During December 1978 the mean value was lower than $200 \mathrm{ppm}$. Following this winter, a long period (Jan to Dec 1979) was characterized by a residual pollution $(\simeq 150 \mathrm{ppm})$. During the $1979-80$ winter period the level of the pollution recovered to normal (prepollution) values (i.e. $50 \mathrm{ppm}$ ). Unfortunately the Brittany coast was polluted again after the Tanio shipwreck in March $1980(10,000$ t of hydrocar- bons) (Bodennec et al. 1983). The mean value from March to August 1980 reached up to $150 \mathrm{ppm}$.

Oil dispersed in an irregular pattern over the mud flat as was shown by large variations in oil content of replicate cores, especially just after the oil spill. In the top layer of sediment, the standard deviation ( $\sigma$ ) for a 6 fold determination in June 1978 exceeded the mean value $(\overline{\mathrm{x}} \pm \sigma=373 \pm 446 \mathrm{ppm})$, whereas in June 1979, for a 17-fold determination, it was lower $(\overline{\mathrm{x}} \pm \sigma=165 \pm 141 \mathrm{ppm})$. The micropatchiness of the hydrocarbons might have been caused by the activities of endofauna such as Nereis diversicolor or Scrobicularia plana. The microstructure may also have concentrated hydrocarbons (cf. Clifton et al. 1984).

\section{Pigment content}

During this study, chlorophyll a concentrations ranged from 5 to $50 \mu \mathrm{g} \mathrm{Chl} \mathrm{a} \mathrm{g}{ }^{-1}$ dry sediment. During the first few months following the 'Amoco Cadiz' oil spill, neither an increase nor a decrease was observed. Values were obviously increasing during the 1978 autumn and winter. Large fluctuations occurred also during this last period (Fig. 2). After this stage, a slight drop of Chl a concentrations during 1979 and 1980 was noted. Moreover a seasonal increase was obvious during early spring (Mar) and late summer (Aug and Sep), whereas an evident decrease occured during winter periods.

The 'tendency extracting program' that had been applied to these data (1979-80-81), calculates the mean seasonal trend around the annual mean level of each year (Fig. 3). The seasonal trend clearly apppears, except for 1978 . The late 1978 autumn bloom was not predicted and the mean trend was abnormally high; furthermore, the March Chl a level (before pollution) was lower than that predicted by calculations.

Seasonal and annual variations of phaeopigments are not as marked as those of chlorophyll a. There was only a slight decrease of phaeopigments during winter
Fig. 3. Chlorophyll a 'seasonalization' Points: mean $\mathrm{Chl}$ a concentration measured each month (last 4 points estimated); horizontal bars: mean for each year; thin and hatched curves: seasonal model calculated from the 1979 to 1981 period; open symbol: prepollution data

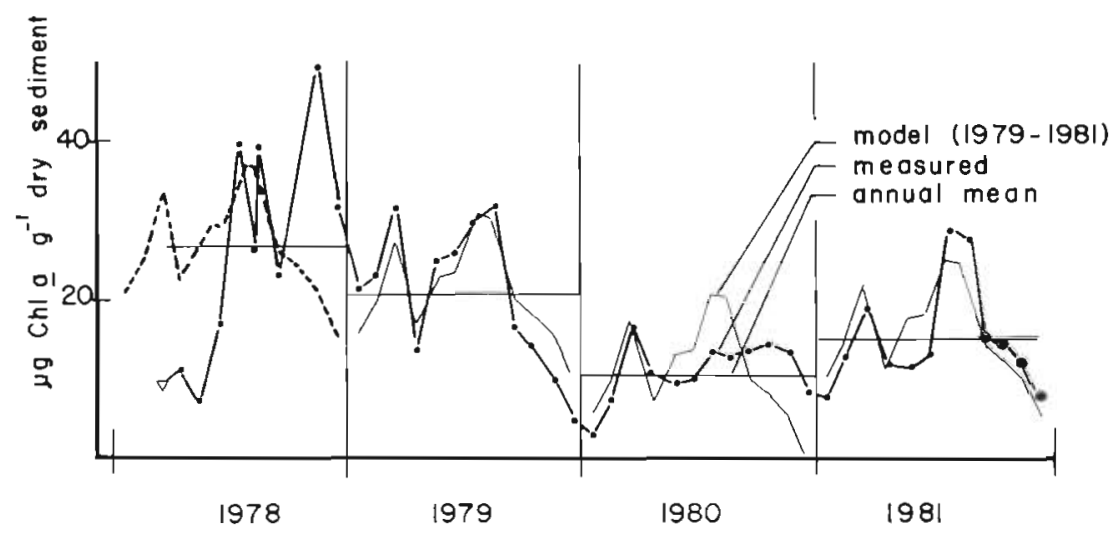




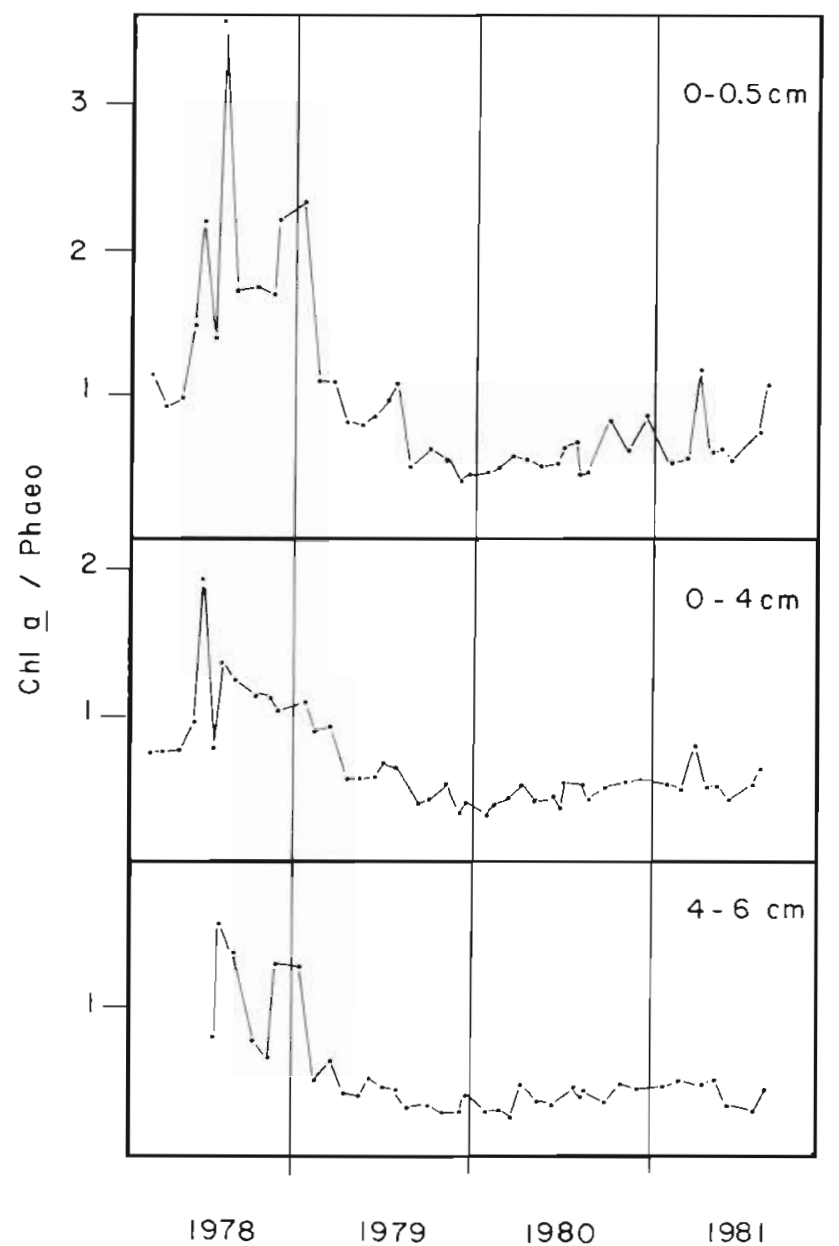

Fig. 4. Chl a/Phaeo ratio in some layers of the sediment

periods and a generally high level in 1979 (Fig. 2). However a long-term trend obviously appears in fluctuations in the ratio $\mathrm{Chl}$ a/Phaeo (Fig. 4). During the first months following pollution, Chl a dominated, after which the products of degradation such as phaeopigments became dominant until 1981. This trend is well pronounced in the top layer $(0$ to $0.5 \mathrm{~cm}$ ) of the sediment but is also detectable in the lower layer (4 to $6 \mathrm{~cm}$ ).

\section{Benthic microalgae: successions and cell numbers}

In order to know which microphytes were responsible for the quantitative variations in chlorophyll a content of the sediment, a study of the dominant species (mainly diatoms and Euglenophyta) was initiated in August 1978. We do not know what changes occurred just after the oil arrival (Mar to Jul 1978), but we can compare species successions and cell numbers which took place during the 4 consecutive years after the shipwreck. The main points are: (1) recurrent seasonal patterns of species successions over the $4 \mathrm{yr}$;
(2) dominance of very small Naviculaceae, nanophytobenthos, during the summer months of each year (Riaux 1983); (3) great fluctuations of the annual variations in cell numbers (Fig. 5).

The trend of variation in the epipelic diatom numbers is quite similar to that of Chl a 'biomass'. Small Naviculaceae, such as Navicula phyllepta or $N$. gregaria, which bloom during summer, have a very low volume $\left(10^{2}\right.$ to $\left.10^{3} \mu \mathrm{m}^{3}\right)$, so cell densities have been plotted (Fig. 5b) on a logarithmic scale in order to make more realistic comparisons with the pattern of Chl a variation.

Euglenophyta were also present in great densities, mostly Euglena limosa and E. cf. vermiformis. These 2 very large microalgae $(150 \mu \mathrm{m}$ long, 20 to $50 \mu \mathrm{m}$ thick, $10^{4}$ to $10^{5} \mu \mathrm{m}^{3}$ volume) must have contributed in large part to the microphytic biomass. A succession of these 2 species took place, even during the most polluted period, and seemed to be reproducible from one year to another (Fig. 5a). E. limosa appeared in spring and $E$. cf. vermiformis some months later. The maxima of cell numbers were observed during the last months of 1978 and the first months of 1979 (up to $15 \times 10^{3} \mathrm{cell} \mathrm{cm}^{-2}$ ), whereas during 1980 Euglenophyta were scarce. The excessive bloom of $E$. cf. vermiformis following the oil spill and the abundance of the 2 Euglena species in the
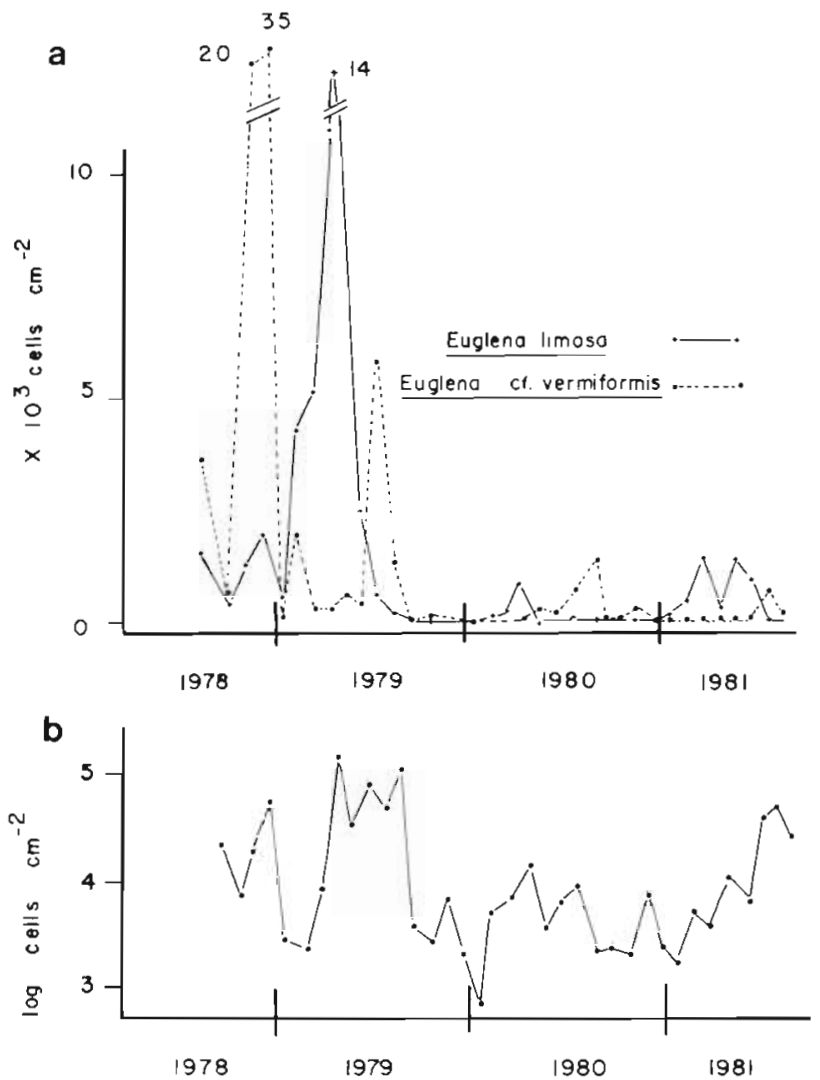

Fig. 5. Microphyte concentrations in the top layer of the sediment. (a) Euglenophyta, (b) epipelic diatoms 
following year suggest that these organisms are selectively stimulated by the pollution.

\section{DISCUSSION AND CONCLUSIONS}

Several long-term variations in microphytobenthos biomass on mud flats (not oil polluted) have been reported. Some authors, such as Aleem (1950) or Colijn \& Dijkema (1981), describe a seasonal cycle in biomass with spring and autumn blooms and a winter decrease, whereas Riznyk \& Phinney (1972), Amspoker \& McIntire (1978) and Cadée \& Hegeman (1974) do not describe such a phenomenon. Some of these authors have suggested that the overall nutrient stock, that exists all year round on these mud flats, can highly favour continuous microphytic growth. The sediments sampled in this study also contained high levels of porewater nutrients, mainly nitrogenous (up to $800 \mu \mathrm{g}$ at $l^{-1} \mathrm{NO}_{3}$ and $100 \mu \mathrm{g}$-at $\mathrm{l}^{-1} \mathrm{NH}_{4}$ ), but another factor of importance is the great tidal range (up to $10 \mathrm{~m}$ at spring tides) that characterizes the Northern Brittany coasts. Thus, a great part of these mud flats can be emerged during a long period of the day and therefore can be subjected to restrictive climatic factors such as intense solar radiation and dessication in summer, and stormy weather in winter. These seasonal climatic fluctuations and stress could induce the cyclic responses that are observed here.

Superimposed on the seasonal cycle, the long-term change that appeared during the study period may be a consequence of the 'Amoco Cadiz' oil spill on this muddy shore. This disturbance is well illustrated by the $\mathrm{Chl} \mathrm{a/Phaeo} \mathrm{fluctuations} \mathrm{(Fig.} \mathrm{4).} \mathrm{However} \mathrm{the}$ cause of this particular trend is not clear. The most realistic interpretation of the unexpected Chl a bloom (in autumn 1978) can be the death, and its consequence, of a part of the macrofauna such as Nereis diversicolor. Some authors found certain benthic polychaetes to be quite resistant to oil pollution (Carr \& Reish 1977, Lee 1977), but others observed severely damaged intertidal macrofauna after oil spills (Spooner 1970, Chia 1971 in Mohammad 1974). The intertidal macrofauna and its long-term changes have not been studied in detail in the Dourduff area, but many observations have been made on other polluted beaches and mud flats near the 'Amoco Cadiz' shipwreck (cf. Chassé 1978). The in situ response of $N$. diversicolor to this oil pollution can be divided in 3 stages (Glemarec pers. comm.) : (1) disappearance during the first 8 to 14 mo following the spill; (2) reappearance and even a bloom (up to 1,000 ind $\mathrm{m}^{-2}$ ) after 17 to $21 \mathrm{mo}$; (3) decrease to prepollution densities after $21 \mathrm{mo}$. So, if $N$. diversicolor and the other grazers have been affected in a similar way on the Dourduff area (in fact in 1978-79 we observed only a few $N$. diversicolor $\mathrm{m}^{-2}$ and up to 400 ind $\mathrm{m}^{-2}$ in 1980) we can reasonably correlate the microalgal bloom to the grazers' decline. Some papers point out the effect of grazing on the regulation of the microphytobenthos populations, especially during summer months (cf. Cadée \& Hegeman 1974). Elsewhere, in pelagic systems, the disappearance of grazers after oil pollution has been reported to stimulate microphyte blooms (Dahl et al. 1983).

\section{SUMMARY}

The sheltered estuarine mud flat sampled in this study (Dourduff, Northern Brittany), was heavily polluted by petroleum hydrocarbons for 4 mo. Sediments contained more than 500 ppm of aliphatic hydrocarbons in the top $10 \mathrm{~cm}$ of the sediment. The top $5 \mathrm{~mm}$ layer was polluted for $6 \mathrm{mo}$, and residual pollution (more than $100 \mathrm{ppm}$ ) lasted more than $3 \mathrm{yr}$.

This study showed the existence of a clear-cut seasonal cycle in microphytic $\mathrm{Chl}$ a biomass and species succession. An important disturbance followed the oil spill. The annual mean trend of the Chl a over the $4 \mathrm{yr}$ following the wreck fluctuated greatly and during the 1978 autumn the biomass showed a very specific pattern. Microphyte growth, particularly of 2 Euglenophyta species (Euglena limosa and E. cf. vermiformis), may have been stimulated by pollution or indirectly by a possible disappearance of grazers.

Acknowledgements. I thank A. Sournia and W. Admiraal for valuable criticisms, A. Laurec for providing the mathematical program, J.-C. Dauvin and C. Hily for helpful discussions. I further thank L. Le Borgne for aliphatic hydrocarbon analysis, $B$. Klein for help in writing the English text, and N. Guyard for typing. The comments of 3 anonymous referees are also gratefully acknowledged. This study was supported by C.N.E.X.O Grant no. 80/6276 and by C.N.R.S.

\section{LITERATURE CITED}

Aleem, A. A. (1950). The diatom community inhabiting the mud flats at Whitstable. New Phytol. 49: 174-188

Amspoker, M. C., McIntire, C. D. (1978). Distribution of intertidal diatoms associated with sediments in Yaquina estuary, Oregon. J. Phycol. 14: 387-395

Bakke, T., Dale, T., Thingstad, T. F. (1982). Structural and metabolic responses of a subtidal sediment community to water extracts of oil. Neth. J. Sea Res. 16: 524-537

Bodennec, G., Pignet, P., Caprais, J.-C. (1983). Le Tanio. Suivi chimique de la pollution pétrolière dans l'eau et les sédiments de mars 1980 à aout 1981. Rapports Scientifiques et Techniques du CNEXO n ${ }^{\circ} 52$

Bodin, P., Boucher, D. (1983). Evolution à moyen terme du méiobenthos et des pigments chlorophylliens sur quelques plages polluées par la marée noire de l' 'Amoco Cadiz'. Oceanologica Acta 6: 321-332

Boucher, G., Chamroux, S., Riaux, C. (1982). Etude d'impact écologique de la pollution pétrolière de l' 'Amoco Cadiz' 
dans la région de Roscoff et de la Baie de Morlaix 'Effects à long terme sur la structure des écosystèmes sédimentaires'. Rapp. Exe. Contrat études environ. CNEXO/Université Paris VI n ${ }^{\circ} 80 / 6276$

Boucher, G., Cabioch, L., Chamroux, S., Dauvin, J.-C. (1983). Veille écologique des côtes bretonnes - Etude du macrobenthos, de la méiofaune et des bactéries en Baie de Morlaix'. Rapp. Exé. Contrats études CNEXO/CNRS n ${ }^{\circ}$ $81 / 6597$ et $n^{\circ} 82 / 2606$

Cadée, G. C., Hegeman, J. (1974). Primary production of the benthic microflora living on tidal flats in the Dutch Wadden Sea. Neth. J. Sea Res. 8: 260-291

Carr, R. S., Reish, D. J. (1977). The effect of petroleum hydrocarbons on the survival and life history of polychaetous annelids. In: Wolfe, D. A. (ed.) Fate and effects of petroleum hydrocarbons in marine organisms and ecosystems. Proceedings of a Symposium, 10-12 Nov. 1976 Seattle, Wash. Pergamon Press, New York, p. 168-173

Causse, C. Mestres, R. (1975). Dosage des résidus d'hydrocarbures par infrarouge dans l'eau de mer et les sédiments marins. In: Manuel des méthodes de prélèvements et d'analyse. Réseau National d'observation de la qualité du milieu marin CNEXO, Brest, 2: 13-18

Chassé, C. (1978). Esquisse d'un bilan écologique provisoire de l'impact de la marée noire de l'Amoco Cadiz sur le littoral. CNEXO. Actes de Colloques 6: 115-134

Clifton, H. E., Kvenvolden, K. A., Rapp, J. B. (1984). Spilled oil and infaunal activity - Modification of burrowing behavior and redistribution of oil. Mar. envir. Res. 11: 111-136

Colijn, F., Dijkema, K. S. (1981). Species composition of benthic diatoms and distribution of chlorophyll $a$ on an intertidal flat in the Dutch Wadden Sea. Mar. Ecol. Prog. Ser. 4: 9-21

Dahl, E., Laake, M., Tjessem, K., Eberlein, K., Bøhle, B. (1983). Effects of Ekofisk crude oil on an enclosed planktonic ecosystem. Mar. Ecol. Prog. Ser. 14: 81-91

Eaton, J. W., Moss, B. (1966). The estimation of numbers and pigment content in epipelic algal populations. Limnol. Oceanogr. 11: 584-595

Elmgren, R., Frithsen, J. B. (1982). The use of experimental ecosystems for evaluating the environmental impact of pollutants: a comparison of an oil spill in the Baltic Sea and two long-term, low-level oil addition experiments in mesocosms. In: Grice, G. D., Reeve, M. (ed.). Marine mesocosms: biological and chemical research in experimental ecosystems. Springer-Verlag, New York, p. $153-165$

Gordon, D. C., Prouse, N. J. (1973). The effects of three oils on marine phytoplankton photosynthesis. Mar. Biol. 22: 329-333

Gundlach, E. R., Boehm, P. D., Marchand, M., Atlas, R. M., Ward, D. M., Wolfe, D. A. (1983). The fate of Amoco Cadiz oil. Science 221: 122-129

Hsiao, S. I. C. (1978). Effects of crude oils on the growth of arctic marine phytoplankton. Environ. Bull. 17: 93-107

Johansson, S., Larsson, U., Boehm, P. (1980). The Tsesis oil spill impact on the pelagic ecosystem. Mar. Pollut. Bull. 11: 284-293

Lacaze, J.-C. (1978). Etude expérimentale de l'influence des produits pétroliers sur la production primaire de l'environnement marin. Thèse Doct. Sci. Nat. Univ. Paris

Laurec, A., Le Gall, J.-Y. (1975). De-seasonalizing of the abundance index of a species. Application to the albacore (Thunnus alalunga) monthly catch per unit of effort
(C.P.U.E.) by the Atlantic Japanese long line fishery. Bull. Far. Seas Fish. Res. Lab. 12: 145-169

Law, R. J. (1978). Petroleum hydrocarbon analysis conducted following the wreck of the supertanker Amoco Cadiz. Mar. Pollut. Bull. 9: 293-296

Lee, R. F. (1977). Accumulation and turnover of petroleum hydrocarbons in marine organisms. In: Wolfe, D. A. (ed.) Fate and effects of petroleum hydrocarbons in marine organisms and ecosystems. Proceedings of a Symposium, 10-12 Nov. 1976. Seattle, Wash. Pergamon Press, New York, p. $60-70$

Lorenzen, C. J. (1966). A method for the continuous measurements of in vivo chlorophyll concentration. Deep Sea Res. 13: 223-227

Mohammad, M. B. M. (1974). Effect of chronic oil pollution on a polychaete. Mar. Pollut. Bull. 5: 21-24

Oviatt, C., Frithsen, J., Gearing, J., Gearing, P. (1982). Low chronic additions of no. 2 fuel oil: chemical behavior, biological impact and recovery in a simulated estuarine environment. Mar. Ecol. Prog. Ser. 9: 121-136

Ozouville, D', L., Gundlach, E. R., Hayes, M. O. (1978). Effects of coastal processes on the distribution and persistence of oil spilled by the Amoco Cadiz - preliminary conclusions. CNEXO. Actes de Colloques 6: 69-96

Parsons, T. R., Li, W. K. W., Waters, R. (1976). Some preliminary observations on the enhancement of phytoplankton growth by low levels of mineral hydrocarbons. Hydrobiologia 51 : $85-89$

Plante-Cuny, M.-R. (1974). Evaluation par spectrophotométrie des teneurs en chlorophylle a fonctionnelle et en phéopigments des substrats marins. Doc. Sci. Mission O.R.S.T.O.M. Nosy-Bé 45: 1-76

Plante-Cuny, M.-R., Le Campion-Alsumard, T., Vacelet, E. (1980). Influence de la pollution due à l'Amoco Cadiz sur les peuplements bactériens et microphytiques des marais maritimes de l'lle Grande. 2. Peuplements microphytiques. In: Amoco Cadiz. Fates and effects of the oil spill. Proc. International Symposium, Brest (France). 19-22 novembre 1979. Paris. CNEXO. 429-442

Prouse, N. J., Gordon, C. D. Jr., Keiser, P. D. (1976). Effects of low concentrations of oil accomodated in sea water on the growth of unialgal marine phytoplankton cultures. J. Fish. Res. Bd Can. 33: 810-818

Riaux, C. (1982). La chlorophylle a dans un sédiment estuarien de Bretagne Nord. Annls Inst. Oceanogr. Monaco 58: $185-203$

Riaux, C. (1983). Microphytes de l'interface 'eau-sédiment' dans une ria de Bretagne Nord: peuplements, biomasse, production, cycle annuel, variabilité à court terme. Thèse Doct. Sci. Nat. Univ. Paris

Riznyk, R. Z., Phinney, H. K. (1972). The distribution of intertidal phytopsammon in an Oregon estuary. Mar. Biol. 13: 318-321

Skjoldal, H. R., Dale, T., Haldorsen, H., Pengerud, B., Thingstad, T, F., Tjessem, K., Aaberg, A. (1982). Oil pollution and plankton dynamics 1 . Controlled ecosystem experiment during the 1980 spring bloom in Lindasspollene, Norway. Neth. J. Sea Res. 16: 511-523

Vargo, G. A., Hutchins, M., Almquist, G. (1982). The effect of low, chronic levels of no. 2 fuel oil on natural phytoplankton assemblages in microcosms: 1 . Species composition and seasonal succession. Mar. environ. Res. 6: 245-264

Yentsch, C. S., Menzel, D. W. (1963). A method for the determination of phytoplankton chlorophyll and phaephytin by fluorescence. Deep Sea Res. 19: 1221-1231 